\title{
International Economic Statistics: Biased Arbiters in Global Affairs?
}

\author{
Daniel Mügge ${ }^{1} \mathbb{D}$
}

Received: 19 October 2018 / Accepted: 29 January 2019 / Published online: 5 February 2019

(C) The Author(s) 2019

\begin{abstract}
International economic statistics play central roles in global economic governance. Governments and international organizations rely on them to monitor international economic agreements; governments use them to understand potential imbalances in bilateral relationships; and international investors build their country assessments on such data. These statistics increasingly suffer from serious defects, however, due to globalization, the digitization of our economies, and the prominence of secrecy jurisdictions and multinational corporations. For that reason, economic data is not a neutral arbiter in international affairs. Instead, it suffers from four kinds of bias: Expert attention bias means that the objects of measurement-what they are meant to capture-depend on the preoccupations of the small circle of statistical experts. Countability bias skews economic figures in favor of countable objects and away from, for example, unremunerated labor and production as well as ephemeral economic process, such as knowledge production. Capitalist bias emerges because economic statistics naturalize unequal power relations in the global economy: They mistake a country's inability to fetch high prices for its products for low productivity and a lack of added value. Stealth-wealth bias, finally, means that statistics naturalize the distorted image we have of the global economy as corporations and individual hide profits and wealth in secrecy jurisdictions. This article cautions against an insufficiently critical use of statistics in international affairs. And it encourages policymakers to "know thy data" lest biases in the numbers generate skewed policies, unnecessary disputes and a gradual delegitimization of statistics in general.
\end{abstract}

Keywords Economic statistics · Global governance · Political economy · International organizations · International agreements

Daniel Mügge

d.k.muegge@uva.nl

1 Political Science Department, University of Amsterdam, Postbus 15578, 1011 NB Amsterdam, The Netherlands 


\section{Introduction}

Economic statistics play an indispensable role in global economic governance. Realists see world politics as little more than a struggle for domination, fueled by mutual distrust and decided by the relative force countries can bring to bear and the alliances they manage to forge. Avoiding such a dog-eat-dog world, countries have built a dense web of international institutions that put the global order on a more solid footing. In international economic governance, harmonized statistics enable governments to order their economic affairs, lubricate their interactions, and mediate potential conflict. For example, balance of payments (BOP) statistics are crucial for the work of the World Trade Organization (WTO) and the International Monetary Fund (IMF); information about per capita wealth levels is important for the World Bank. Government debt statistics underpin European Union arrangements for the single European currency. International investors base their assessments-and investment decisions - on country-level economic data.

A basic trust in the solidity of these data in turn undergirds governments' support for an open international economic order. Both public and private actors need faith that statistics can count as neutral arbiters in global affairs. On that basis, they accept economic statistics as monitoring devices for international economic agreements. These figures also offer countries information about their bilateral economic relationships, and they provide the lenses through which international institutions, and by extension international investors and domestic governments themselves, perceive economic developments.

Yet, economic statistics are far from value-neutral. There are no self-evident ways to measure things like public debt, economic growth, services trade, or portfolio investment. International economic statistics frequently suffer from poor quality (Jerven 2013; Linsi and Mügge 2019; Morgenstern 1963). These problems have grown over time. Measurement standards were designed in an era when manufacturing was the dominant economic sector, and when global production and wealth chains were relatively simple. We now live in a different age. Countries outside "the West" have risen to global prominence; poorer nations are not easily sidelined anymore; and democratic, market-based capitalism no longer is the convergence point for economic growth models around the world. In addition, the complexity of the global economy has increased enormously, both through more complex production and wealth chains and through the digitization of economic activity and new patterns of wealth creation. International economic statistics reflect a mind-set that is increasingly at odds with the present-day reality.

What does this potential mismatch mean for the role that economic statistics play in international politics? More specifically, what kinds of biases may international economic statistics introduce into global affairs? The scope for such skew becomes clear once we consider the different steps in the assembly of global statistics. The standards that underpin them have to answer four questions: First, what should be measured? Should it be merchandise trade, or poverty, or an ecological footprint? Second, what should be included in each measure? Should a trade measure include holidays abroad, or example, or for-free services such as Google Maps? Third, how 
should the different components be counted or valued? And fourth, how is what we measure attributed geographically?

I argue that the real-world answers to these questions introduce biases. Thus, we cannot assume international economic statistics to be neutral arbiters in global affairs. First, expert attention bias means that choices about what is to be measured are primarily driven by experts from highly developed countries in international organizations. International economic statistics reflect their concerns and perspectives. Second, countability bias means that a statistical perspective systematically privileges those facets of economic life that are easily countable. On the one hand, that introduces materialist bias, which skews our image of global economic relationships in favor of easy-to-count tangibles, at the expense of ephemeral capital flows, services trade, or intangible factors of production. Trade and assembly hub bias follows directly: Because net trade flows and value added per country are hard to observe, statistics focus on gross flows and thereby exaggerate the importance of trade hubs and final assembly locations. On the other hand, the need to make things countable introduces monetary bias. It prioritizes production and labor that are traded for money and sidelines production and labor that remains un-marketed or unpaid, frequently performed by women in domestic or subsistence agricultural contexts.

Third, statistics aggregate disparate products and assets through their prices. They ignore how these prices reflect not only the intrinsic value of things, but also the unequal power relations and terms of trade under which things are produced and exchanged. This conflation of prices and intrinsic values creates capitalist bias. Rather than problematizing inequalities in the global economy, economic statistics naturalize them. Finally, complex derivatives and corporate structures, legal trickery and secrecy jurisdictions spawn stealth-wealth bias: Large corporations and rich individuals can reorganize wealth and production for accounting purposes in ways that swing free from actual productive processes. Our view of where value is created and who owns it is systematically distorted as a consequence.

In principle, the attempt to base global affairs on a shared and objective understanding of the world around us-what you could call the neutrality norm-is laudable. Informed debates about potentially unfair trading practices are impossible unless countries agree on the numbers that describe their economic relationship. My aim is not to disparage economic statistics or the efforts of those who collect them. High-quality economic statistics are indispensable for ordered economic affairs. It is because of this importance that I critically examine their ability to play that role without bias.

This article makes two contributions. On an academic level, it argues that scholars of international relations, international political economy, and global governance should no longer see economic statistics as neutral grease on the wheels of international cooperation. Instead, these numbers are socially crafted tools that bear the hallmarks of their genesis (Mügge 2016) and thereby introduce (potentially unintentional) skew into international cooperation. When studying the politics of such cooperation, we should include statistics in our analysis in that spirit. 
This argument also has direct practical implications. We naturally look to data to adjudicate between competing claims. But for statistics to fulfill that role legitimately, policymakers and citizens need to appreciate the biases that may be lurking in the numbers. Otherwise, economic statistics may produce discord when they remain disputed - as in international trade conflicts-or poor policy when they are taken too seriously. Both of these dynamics corrode the highly institutionalized and relatively cooperative mode of global governance that has characterized the recent decades.

The rest of the article is structured as follows: The next section details the three main functions that economic statistics play in global affairs: as monitoring devices for international agreements and organizations, as yardsticks for countries to assess their bilateral affairs, and as legibility templates through which both international investors and domestic policymakers view economic and social development. I then introduce a more critical perspective on statistics, which highlights their growing defects and historical biases. The body of the article itself outlines the four main forms of bias that deserve our attention and illustrates with practical examples when and how they matter.

\section{International Economics Statistics as Arbiters in Global Affairs}

Economic life has been quantified for millennia (cf. Sedlacek 2011). Debt registers are among the earliest written records we have (Graeber 2011). For ages, political rulers have worried about their relative military might, and by extension about their ability to translate a national economic surplus into raw material for warfare. English mercantilists, for example, inquired into the sources of Dutch wealth, which let the little republic punch far above its weight in the geopolitics of the day (McCormick 2009). At the same time, the British crown supported William Petty's development of Political Arithmetick-socioeconomic statistics in embryonic form meant to bolster the English domination of Ireland. In the seventeenth century, these were combined with population statistics, and during the centuries since then, national accounts have emerged to capture the essential properties of national economies (Kendrick 1970; Kenessey 1994; Studenski 1958).

Initially, these data collection enterprises were neither harmonized nor intended for international governance. National income estimates proliferated in the nineteenth and early twentieth century, but most were home-grown initiatives that selectively copied ideas from each other (Studenski 1958). In the 1930s and 1940s, Colin Clark, Simon Kuznets, and Richard Stone all made key contributions to what was eventually to become gross domestic product (Coyle 2014; Lepenies 2013; Masood 2016; Philipsen 2015), but also they were interested in better domestic economic management much more than in cross-border comparability.

Considering how ubiquitous internationally harmonized statistics are these days-most importantly in the form of the System of National Accounts (SNA) and balance of payments (BOP) statistics - it seems remarkable how relatively late harmonization emerged. But upon reflection, beyond emulating others' best practice, it is not obvious why countries would solidly commit to internationally shared 
statistical standards. After all, those standards might tie them to measurement routines and definitions at odds with domestic conditions without immediate benefits.

That internationally harmonized statistics emerged nevertheless is largely owed to the spirit of international cooperation and developmentalist optimism prevailing at the United Nations just after their establishment (Ward 2004). Inspired by what were seen as the pre- and interwar failings of international economic liberalism, even the leading capitalist nations had resolved to build a much more publicly managed international economic order (Block 1977; de Cecco 1979; Helleiner 1994), with an international payments system supervised by the International Monetary Fund (IMF) and a trading order that was eventually governed by the General Agreement on Tariffs and Trade (GATT). The IMF Articles of Agreement limited crossborder capital movements, and to monitor whether IMF member states were playing by the rules, they needed to submit comparable and trustworthy financial flows data. The need for standardized balance of payments statistics followed directly.

This monitoring function matters a fortiori when international agreements are not only binding on paper but tied to sanctioning mechanisms. Most notably, the European Union's Stability and Growth Pact famously specifies upper limits for government debt stocks and annual budget deficits. Once these limits had been agreed in principle, a complicated negotiation followed to detail how government debt would be calculated, and how Eurostat could go about monitoring government finances in an impartial way (Savage 2005).

In addition, internationally harmonized statistics provide countries with tools to assess their bilateral relationships using mutually agreed yardsticks. Such harmonized statistics might reveal, for example, how large a merchandise trade deficit one country would have with another one, or what kind of an investment position. Potential debates about redressing undesirable imbalances would have a secure footing.

At the same time, an optimistic, universalist developmentalism flourished at the UN and beyond after the Second World War-a technocratic belief that economic progress was engineerable through smart public management. This numbers-based economistic approach to development has increasingly displaced more experiential, historical, or geographically informed statecraft (Scott 1998). And it too has buttressed a concerted effort to forge statistical standards that would eventually generate the data not only to promote post-war reconstruction but also to aid the development efforts of newly independent nations such as India or Pakistan (Masood 2016).

If economic statistics provide legibility templates for national economies, they work that way not only for policymakers but also for international investors, who increasingly practice economic assessment by the numbers (Abolafia 2010; Beckert 2016; even if these figures still require interpretation, cf. Leins 2018). These investors shape national policies through their decisions to invest or withdraw funds (Frieden 1991; cf. critically Mosley 2003). That makes the information on which they base their assessments political. International organizations that design statistical standards thus have an implicit obligation to make sure that these standards generate information that contributes to fair outcomes once investors start using it.

The trend toward a quantification of international economic life has only intensified in recent decades. International organizations, now also including the Organization for Economic Cooperation and Development (OECD), have stepped up 
their data collection and analysis efforts; the IMF these days publishes government finance statistics to a surprising level of detail. The international embrace of the sustainable development goals, undergirded by more than 150 indicators to measure progress, starkly illustrates the datafication of global governance (Data Revolution Group 2014). ${ }^{1}$

In essence, then, economic statistics perform three functions in global affairs: They are monitoring devices for international organizations and the agreements they guard. They offer countries information about their bilateral economic relationships and potential imbalances therein. And they provide legibility templates for international (development) organizations, and by implication for both national governments and international investors.

Statistics are essential to all these functions: They can be seen as arbiters where opinions differ. Genuine international deliberation, which transcends strong parties simply imposing their will on others, requires a shared understanding of contentious economic circumstances. For economic data to fulfill these arbiter-functions, the public and private actors involved need faith in the data, and they need to accept it as a neutral reflection of economic circumstances - data need to fulfill what I have earlier called the neutrality norm. Yet as it turns out, economic statistics are susceptible to biases that can frustrate their ambition to function as impartial referees in global affairs.

\section{Economic Statistics as Biased Social Constructs}

The quality of balance of payments data is surprisingly poor. Together with Lukas Linsi I have examined large swaths of trade and investment data and frequently found uncertainty margins of 20 percentage points in the figures reported by the IMF (Linsi and Mügge 2019). Our analysis followed a straightforward approach: In principle, the IMF's direction of trade statistics database (IMF DOTS) records every aggregate intercountry flow twice-once as reported by the sending country, and once as reported by the receiving country. Large discrepancies between these figures indicate serious measurement problems.

The figures we analyzed revealed, for example, that US-Chinese disagreement about these countries' bilateral trade balance in 2014 amounted to roughly $\$ 100 \mathrm{bn}$. The Canadian-American discrepancy in trade figures still amounted to $\$ 52 \mathrm{bn}$; that across the Mexican border to $\$ 49 \mathrm{bn} .^{2}$ Notably, the direction of these disagreements was not always what one might expect as a result of political tampering: US estimates of its trade deficit with Mexico, for example, have been much lower than what Mexican authorities have reported (Mügge and Linsi 2017). And while data

\footnotetext{
1 A related trend has unfolded outside of international public organizations, as transnational advocacy groups have embraced rankings and manifold indicators to exert soft power over governments (Broome and Quirk 2015; Kelley 2017).

2 Such discrepancies are pervasive. In another example, the US reported \$47bn in merchandise imports from France for 2014; France itself claimed to have exported only \$37bn in merchandise to the USA-a difference of more than 20\%. For more examples, see Linsi and Mügge (2018).
} 
quality has been poor for merchandise trade statistics, it has been worse for more ephemeral BOP components: services trade, foreign direct investment, and portfolio investment.

The causes of faulty international economic data are manifold. Some stem from limited statistical capacity especially in poor countries (Jerven 2013). Others may be rooted in conscious data tampering, for example to stay on the right side of numerical thresholds for aid eligibility (Kerner et al. 2017) or because autocrats in particular may report overly flattering figures to international organizations (Hollyer et al. 2011). While such effects clearly matter for international data quality, they fall outside the scope of this analysis, because they stem from a country's inability or unwillingness to provide high-quality data. The question here, in contrast, is whether the international data standards that we use do themselves skew global economic affairs-even when countries can and want to play by the international rules.

We can divide data defects into random error and systematic bias. Only the latter is relevant for the charge that economic figures consistently distort global affairs; by definition, random error would privilege one actor at one juncture, and another at another one. While unfair in each particular instance, it would remain unclear ex ante who would benefit and who would lose from any particular set of statistics. Bias is different. Information that looks like a straight answer to a question-which country exports a lot and which country exports less-may in fact be systematically skewed, benefitting one category of countries at the expense of the other.

The data-driven exercise with Lukas Linsi mentioned above frequently had to remain agnostic about the nature of the number-problems we discovered-random error and systematic bias are hard to tell apart when we are in the dark about the source of the data disparities. What the exercise did reveal, however, is that both are huge. It also showed that data defects are growing rather than shrinking. The increasing complexity of global production chains and money flows-including through the use of derivatives-makes it ever more difficult to track these flows and to assign them unambiguously to specific jurisdictions (Bryan et al. 2017). This problem is amplified by the rise of ephemeral digital products-some of which are provided to consumers without direct charge - and the rising knowledge intensity of production (cf. Baldwin 2017; Bean 2016).

This paper approaches the problem from the other end, investigating the forms of bias that can arise in international economic statistics. The following sections systematize these biases and link them to specific areas of global affairs, drawing out how they skew international cooperation. It summarizes them under four headings: expert attention bias, countability bias, capitalist bias, and stealth-wealth bias.

\subsection{Expert Attention Bias}

Experts from highly developed countries in international organizations largely determine what gets measured and how. The resulting expert attention bias is the most encompassing and abstract form of bias in international economic statistics. The UN-sponsored SNA, for example, contains the intellectual framework for gross domestic product (GDP). Originally, this global template was effectively a transplant 
of ideas that had been developed in the USA and the UK (cf. Lepenies 2013). John Maynard Keynes' former student Richard Stone had systematized national accounting ideas around the end of the Second World War and convinced US officials to follow his lead. ${ }^{3}$ US authorities then exported their national GNP (gross national product, the precursor to GDP) to Europe as an economic monitoring tool attached to the Marshall Plan. From there, it was picked up by the United Nations Statistical Office, which published Stone's System of National Accounts in 1953 (Ward 2004, 45).

Initially, the UN statistical system was in the hands of a very small group of people, but they determined the basic direction of the enterprise. ${ }^{4}$ Michael Ward, a former leading World Bank statistician, later lamented a disproportionate emphasis on the measurement of economic production and growth (Ward 2004). In this, he identified the predominant concern of industrial nations with post-war reconstruction. Many other countries around the world-or countries to be in the case of whose who had yet to gain independence-faced challenges that GNP or GDP statistics capture poorly: for example hunger and malnutrition, low levels of agricultural productivity and education standards, and so on. ${ }^{5}$ For an organization devoted to world peace and the improvement of humanity's lot, the UN's statistical focus on developed country economic problems is noteworthy and consequential. By highlighting some features of our economies and leaving others invisible, statistics can unwittingly direct our attention and steer us in the direction of specific solutions. Misleading statistics about ballooning derivatives markets before the financial crisis had buttressed a false sense of complacency in Europe and North America; poor statistics about income and wealth distributions inside countries there had obscured skyrocketing inequality since the 1980s (Hirschman 2016).

Today, the sustainable development goals cover a broad range of social, economic, and political aims, and frequent progress monitoring is an integral dimension of the effort (Data Revolution Group 2014). Again, however, we must ask to what degree the more than 150 indicators used are slanted by the beliefs and convictions of the experts who have designed them. In any case, the information that we have about the economic relations among nations reflects the preoccupation and interests of those with the power to determine what gets collected and what does not.

\footnotetext{
3 In doing so, US statistical authorities discarded some of Simon Kuznets' ideas, who had developed the first US National Income estimates in the 1930s. Stone, and current GDP measures with him, saw government production as part of the national product. Kuznets was firmly opposed to the idea but lost the argument (Fogel et al. 2013).

4 Six statisticians attended the first meeting of the UN Nuclear Statistical Commission in 1946, hailing from the USA, the UK, India, France, China, and Norway. The Soviet delegate arrived too late to attend; the Brazilian one had eventually canceled his participation (Ward 2004, 37).

5 Masood details this dynamic for Pakistan in the 1950s: The narrow focus on economic growth underlying GDP statistics - an expansion of industrial production or for-the-market agriculture - sidelined many of the more immediate problems that Pakistan's population faced and that might have been addressed without concentrating all energy on this specific dimension of productive activity (Masood 2016).
} 


\subsection{Countability Bias}

Once it has been decided what should be measured-whether income inequality, portfolio investment, or the gender pay gap-we need agreement on what is included in any measure, and how so. That question is less trivial than it sounds. Does income inequality include non-monetary income, for example from subsistence agriculture or the non-monetary services provided by occupier-owned dwellings? How does it treat on-paper capital gains? Intuitively straightforward concepts become much less so once we try to measure them.

Inevitably, quantification entails simplification and, to some degree, reductionism. Boiling matters down to their essence and making them manageable is the great virtue and attraction of statistics (Porter 1995; Wise 1995). At the same time, it introduces important but largely unacknowledged biases into the figures we use. The ambition to summarize our surroundings in numbers concentrates our attention on those dimensions that are relatively easy to quantify. The result is what I call countability bias: Things that are countable end up in the statistics; those that are important but ephemeral are effectively ignored.

Take the example of public debt measures, which loom large in the European Stability and Growth Pact, and which can, if deemed excessive, trigger investor panic and debt crises (Reinhart and Rogoff 2009). While "government debt" sounds like a clear-cut concept, it is surprisingly fuzzy around the edges (de Vlieger and Mügge 2018). Some important government liabilities are conditional, for example, on the occurrence of bankruptcies or natural disasters (Bloch and Fall 2015). Do they count as debt? By the same token, it remains unclear how statistics should deal with pension promises that governments have made to their employees and citizens. Experts agree that such pensions constitute fiscally relevant, if not outright threatening, liabilities. Yet a net present value for them is hard to agree, if only because in some cases governments have the option to renege on their payout promises as an ultimate escape hatch. Hence, what is deemed important in principle-pension liabilities-is readily ignored because it defies reliable quantification. Given that countries have widely differing pension systems, this exclusion systematically benefits governments that have made huge promises to employees and citizens, and it disadvantages those who have not. The effects of including various elements can be substantial: In the Canadian case, depending on whether one would use the most narrow or most expansive definition of public debt, its 2010 value would range between roughly 38 and 104\% of GDP (Bloch and Fall 2015, 11; see de Vlieger and Mügge 2018 for a range of other examples).

In addition to the sidelining of hard-to-quantify aspects of economic life in statistics, countability bias skews economic measures in two ways that deserve specific consideration: in favor of material (factors of) production, and in favor of monetary measures. Let us consider material bias first. International economic transactions that involve the cross-border transport of material goods-cars, computers, cucumbers, etc. - are much easier to trace and allocate than immaterial transfers, both services trade and elusive capital flows. At the margin, that induces an excessive focus on easy-to-track economic relationships, in particular merchandise trade. Manufacturing-heavy countries such as China and Germany, who often run merchandise 
trade surpluses, are then accused of unfair practices, even if other dimensions of international economic interactions, such as controlling stakes in other countries' industries, may just as well be signs of economic domination. ${ }^{6}$

This bias in favor of countable, easy-to-quantify (physical) products also exaggerates the size and importance of trade and assembly hubs in international economic statistics. To characterize a bilateral trade relationship, we would in principle be interested in the quantity of domestically manufactured products two countries exchange. And if products contain input from several countries, we would want to net third-country contributions out of the bilateral relationship lest they distort the picture.

Gross trade statistics fail on both counts. In the case of trade hubs like Singapore or the Netherlands, import statistics will not initially distinguish between goods imported for immediate re-export and those destined for domestic consumption. Conversely, a big chunk of Dutch "exports" to neighboring Germany are in fact imports from third countries that are shipped on after their arrival in the Rotterdam harbor. This effect again is sizable: Between 2004 and 2015 the two countries disagreed about their bilateral merchandise trade relationship by more than 17 percentage points over the overall trade volume-largely a result of what you could call the Rotterdam harbor effect. ${ }^{7}$

In the case of large-scale assembly skewing statistics, China remains the most prominent example. Official rules of origin both for trade agreements and for trade statistics are complicated (e.g., Markhonko 2014), but in essence, products are often registered as imports from countries where they have been assembled, ignoring that the final merchandise contains many constituent parts from third countries. A significant share of the American trade deficit with China is, in fact, a trade deficit with the countries that contribute the constituent components and raw materials that China turns into final products. ${ }^{8}$

\footnotetext{
${ }^{6}$ This unwitting focus on merchandise trade as a proxy for economic relationships more broadly prevails not only in politics and popular reporting on economic affairs but also in academic research about trade politics. Given the dearth of high-quality services trade statistics, scholars often opt for merchandise trade statistics instead without highlighting that switch in the reporting of results as much as it would deserve.

7 To calculate this figure, I first calculated what each country had to say about the trade balance and then established the difference between those two figures. I then divided the difference by the average overall trade volume (the average of what the Germans and the Dutch have to say about imports plus exports). The $17 \%$ is the average ratio between the two figures over 12 years. In no single year was the discrepancy below 11 percent. Raw data are from the OECD STAN Diadyc trade dataset.

${ }^{8}$ The OECD has long recognized this problem but struggled to build a credible database that would convincingly capture trade in value-added (TiVA). In recent years, it has started to generate such statistics. But they are not (yet) in widespread use, and popular politics, as well as international trade agreements and the like, continue to focus on the gross figures. In spite of the considerable efforts invested in the project, Nadim Ahmad, Head of the OECD Statistics Division, himself recently offered a sober assessment of the TiVA data: "The development of TiVA type statistics is certainly a step-forward in this area but these too suffer from the stove-pipe approach used in statistical data collection." See Ahmad (2018), Accounting frameworks for Global Value Chains: Extended Supply-Use tables, http://papers.nber.org/ conf_papers/f100626/f100626.pdf. On the TiVA initiative in general, see http://www.oecd.org/sti/ind/ measuring-trade-in-value-added.htm.
} 
In short, from the perspective of importers, trade hubs and final assembly countries look like bigger exporters than they in fact are. The political dynamics thus unleashed may be unwarranted if one took a more holistic view. Considering the upheaval about trade relationships in the USA since the beginning of the Trump presidency, it is clear that distortions in trade statistics can have quite significant consequences.

In addition to material bias, the privileging of easy-to-count units also introduces monetary bias. Most economic statistics aggregate highly diverse products and flows, and a shared unit of account is necessary to compress all these into a single figure. Sometimes, common traits such as the energy content of fossil fuels or the number of containers shipped from A to B help summarize complex trade patterns. By far the most common unit of account, however, remains money. With the exception of unemployment figures, all major macroeconomic indicators use money as the unit of account or describe properties of monetary values (for example inflation measures).

The attraction of using monetary values is obvious: It allows the aggregation of highly diverse products - smart phones, jeans jackets, barrels of oil-into a single figure. Even better, many products have price tags directly attached to them; that makes information compilation relatively easy. (Think again of other ways of summarizing economic activity, for example through its energy content, the amount of labor invested, or the aggregate utility of the products. All those might offer interesting information, as well, but would be much harder to compute than GDP figures that essentially add up the market prices of final products).

A pecuniary lens on society immediately privileges production and labor that are directly tied to money. Forms of wealth, production, and labor that do not come into contact with money or do not have an obvious monetary value are sidelined, thus generating skewed images of the relative wealth of nations. Relatively rich, industrialized countries tend to feature higher degrees of marketization and commodification: A higher share of production is sold and bought on markets. In many poor countries, in contrast, subsistence agriculture plays a vital role in social reproduction. In rural areas acquisition of foodstuffs for money may be the exception rather than the rule. The term barter has an archaic ring to it, but in the absence of organized, monetized markets, people may provide each other directly with everything from building materials and car parts to livestock and fuel. Large parts of these transactions go unrecorded. In theory, the SNA recognizes goods production even where no exchange for money takes place. In practice, of course, there is no way of putting a reliable monetary value on unobserved trades or untraded products. Poor countries look even poorer than they are because many economic transactions remain below the radar of economic statistics.

The same is true for unremunerated reproductive labor in the household (Waring 1999). Many of these activities have been commodified and outsourced in richer countries: dwelling maintenance, meal preparation, cleaning, care for children as well as for old and sick people, and so on. Since the 1950s already, SNA statisticians have recognized the problem and asked whether and if so, how, domestic labor should be included in aggregate GDP figures (Studenski 1958). In the end, these activities remained outside of the SNA's purview (Lequiller and Blades 2006, 107), 
both because they proved impossible to quantify reliably and because they would just invite further questions about the proper boundary between productive and nonproductive activities. ${ }^{9}$

The point here is not where that boundary should rest, but that its current location biases production statistics in favor of highly commercialized and commodified countries. Who ultimately benefits from this skew is less clear. Ceteris paribus, it makes poor countries look even poorer, and it might induce a higher willingness of rich countries to support them. More pertinently, it distorts the relative wealth of poor countries that are rural (and hence less commercialized) versus those that are relatively urban. Such distortions can in turn feed assessments by the World Bank about who is deserving of international aid. They can also bias international development policy in favor of further commercialization, for example because subsistence agriculture is, through its off-the-radar character, underappreciated as a source of production (Varga 2018).

GDP is a poor yardstick for the wealth of nations not only because it unduly privileges the money economy. It also ignores countries' asset bases (cf. Stiglitz et al. 2010). The Netherlands are a good example. High productivity and a thoroughly commercialized society support high GDP per capita values; at the same time, the country is poor in natural assets. Considered thus, many "poor" nations are significantly richer than a country like the Netherlands.

Some alternative approaches to measuring national wealth have tried to integrate flows and stocks. But the measurement of stocks of human or natural capital (Costanza et al. 1997) in the end proved so thorny and contested that it has remained outside the purview of established economic statistics. The United Nations Statistical Division has mounted a valiant attempt to represent societies' wealth and production holistically in its new System of Environmental Economic Accounting (SEEA). But it, too, has so far gained minimal traction. The dominant depictions of economic activity and prowess continue to be dominated by a narrow, materialist and moneyoriented measure.

\subsection{Capitalist Bias}

The focus on monetary values introduces a second dimension of bias: It preconfigures how the things that are included in our statistics are valued. The preceding section suggested that production factors like natural capital and human capital remain outside core macroeconomic accounts because their measurement is so complicated. Yet the difference between easy-to-find values for actual economic transactions and the ephemeral nature of everything else is more apparent than real.

\footnotetext{
9 The heavy overrepresentation of women in unpaid production and social reproduction introduces gender bias into economic statistics. This not only renders socially necessary labor invisible; it also makes countries with divergent divisions of labor between the genders hard to compare. This is an important and longstanding concern; it remains outside of the scope of this article, however, because it has no direct bearing on the ability of economic statistics to perform their information function in global affairs and is a consequence rather than a source of statistical problems.
} 
The root problem is that economic statistics erroneously conflate prices and inherent values (cf. Smith 2012), a dynamic that is at play with respect to both trade products and capital stocks. As classical political economists already realized, the exchange value of goods and services is not a direct reflection of some inherent use value. It also bears the imprint of, for example, scarcity or other dynamics such as competition restrictions through which either sellers or buyers can enforce advantageous prices. Prices can be pushed up or down through political institutions-customs, taxes, government enforced monopolies, extortionist trade arrangements, and so on. Observed prices are thus as much a function of political institutions and power dynamics as of commodities' narrowly conceived economic properties (Mügge and Perry 2014; cf. Perry 2009).

The same is true for the valuation of capital stocks (Nitzan and Bichler 2009). In principle, the net present value of capital assets is a function of the money that can be earned in the future through their possession. This earnings-capacity itself depends on the political and social context, however: A copper mine is much more valuable if its owner is allowed to ignore environmental damage or to exploit his workers. The market value of capital assets, in other terms, is not only a function of some inherent productive potential but also of the conditions under which these assets can be employed-in short, of the asymmetrical power relations in the global economy.

Capitalism presents capital as a thing rather than as a social relation. Statistics then disguise these power relations by presenting realized prices as properties of the goods and services that were produced, not as reflections of the conditions under which they were made and traded. A country may thus look unproductive, even if in fact it is merely unable to appropriate the produced surplus itself and sees it siphoned off elsewhere.

Such dynamics are everything but new, and Marx famously discussed and decried them. When we are interested in statistics that reflect volumes of monetary transactions, prices may indeed seem appropriate, regardless of their potential disconnect with the international terms of trade or the domestic distribution of profits and wealth. Yet, international economic statistics also inform our economic analyses and notions of international fairness. Countries that earn relatively little for their exports may stand accused of low productivity, seemingly justifying the relatively little money earned there or the need for fundamental reforms. In fact, productivity may be just fine, and it is the inability to charge higher prices that is the problem.

Capitalist bias is different from the other forms discussed so far because it skews data not in favor of one or the other country, but instead legitimizes the global economic order as a whole. It builds on data that emerges out of the social relations as they are ordered, and it facilitates its management on that basis. In that sense, international economic statistics are tools to smoothen the functioning of our economic order or to carry out disputes within those capitalist parameters. Economic statistics offer us no ready tools to critique that order, should we regret the global distribution of surplus as it exists.

To be sure, to say that the naturalization of current economic power relations is the effect of economic statistics is not to say that it is their function, nor is it to say that those crafting the statistics are intent on disguising the true power relations in 
and between societies. Monetary values are obvious units to aggregate diverse products into a single number; as pointed out above, alternative yardsticks, such as the labor input or the utility of products, are hard to determine with any reasonable reliability. By rendering invisible the social roots of the terms of trade, they nevertheless stabilize the current global economic order and deflect attention of the problems of that order to those within it.

\subsection{Stealth-Wealth Bias}

The final question to be answered when building statistics is how production and wealth are attributed to various jurisdictions. That is easy enough when the products in question are produced in a single country or the wealth - say, a factory buildingis located in a single town. The present-day global economy knows not only highly complex global value chains, however, but also impenetrable global wealth chains (Seabrooke and Wigan 2017).

The legal attribution of ownership and production is highly complex, and we will limit ourselves to four complications that introduce the most obvious biases into international economic data: First, large amounts of global financial wealth are held in or channeled through secrecy jurisdictions, such as the Cayman Islands, which obscure ultimate ownership (Sharman 2010; Shaxson 2012). Second, the increasing use of derivatives creates cross-border liabilities without any attendant money flows, such that the "geographical location" of ownership and financial exposures becomes hard to determine, if not entirely meaningless (Bryan et al. 2017, 54f).

Third, large multinational corporations can represent their structure and activities to the outside world in ways that are not primarily guided by their actual operations but by the legal and financial incentives that particular representations carry. Complicated corporate structures include the establishment of legal entities in low-tax jurisdictions and the legal transfer of production factors to these entities-for example ownership of licenses and patents-that swing free from the actual productive process (see the examples in Finér and Ylönen 2017).

Finally, a large chunk of global trade happens inside of multinational enterprises. To gauge the value of the products that companies ship across borders from one branch to another, we rely on the transfer prices they submit. Transfer pricing is not a free-for-all; in principle, corporations have to abide by rules to determine the figures they report (Ylönen and Teivanen 2018). In practice, however, the ambiguities are large enough to give companies sufficient leeway to mold the image of their intra-firm trade thus that it minimizes their tax bills (Christensen 2018). The incentives that companies have to distort this information to take advantage of regulatory and tax differentials also infect the official statistics built on these data (Bruner et al. 2018; Guvenen et al. 2017).

The point is not that it would be easy to identify what the appropriate distribution of value creation across multiple jurisdictions should be. Indeed, that is impossible if only because the knowledge that feeds production has no national home, and because the relative contribution that knowledge (or any other form of capital) makes to production is impossible to determine. Rather, how transactions are 
structured and "booked" is a function of the legal environment in which they unfold. The effects can be enormous. UNCTAD, for example, has estimated that nearly $20 \%$ of global FDI flows in 2015 were in fact funds that were round-tripped through offshore special-purpose entities back to the domestic economy (UNCTAD 2016), for example to hide the wealth or take advantage of foreign tax regimes. According to the calculations of Tørsløv et al. (2018), 40\% of multinational profits are channeled through low-tax jurisdictions. Even if we treat such figures with the caution that this article advocates for other data as well, it is clear that these dynamics have the potential to skew our quantitative image of the global economy substantially.

The resulting biases point in different directions. They clearly inflate the economic role of secrecy jurisdictions and the so-called tax havens (Fichtner 2016; Garcia-Bernardo et al. 2017). Whether they exaggerate the economic roles of richer or poorer countries is less obvious. As shelters for wealth, secrecy jurisdictions downplay the economic dominance of the ultimate beneficiaries' home countriesbe they oil-rich Arab countries, the USA, or nations with a new crop of super-rich individuals such as Russia or China. The governments of the countries in question (and their tax authorities) may not be able to benefit from the wealth that their citizens harbor offshore. Ex ante, that makes it ambiguous whether it is useful to classify wealth hidden abroad by, say, German citizens as German if German authorities are unable to access and tax those funds. That said, it clearly skews our image of the global wealth and power distribution if we ignore where the ultimate beneficiaries live.

The direction of the bias that transfer pricing introduces in global economic affairs is ex ante unclear. At the margin, more value creation (and hence taxable profit and "product") will be attributed to countries in global value chains that offer advantageous tax conditions (cf. Ylönen and Teivanen 2018). Here it is hard to generalize: Governments often arrange custom-tailored tax deals with large companies, as for example Luxembourg and the Netherlands have prominently done in Europe.

Still, corporate figures, which feed global economic statistics, represent an artificial accounting image of the global economy, not the actual distribution of wealth and production. Even if it depends on the specific case at hand in which direction stealth-wealth bias tilts global affairs, the distortions in global economic statistics, and hence in the decisions based on them, are substantial.

\section{Conclusion}

Global economic governance rests on commonly accepted figures that describe the basic contours of the global economy: who trades with whom, where money flows originate, or who benefits from cross-border investments. In agreements about trade and investment flows, but also in investment and domestic policy, international economic statistics are then taken as raw material for decisions and as neutral arbiters should differences of opinion emerge. In that way, economic statistics are an important pillar of ordered global affairs and part of the contemporary normative basis of global governance. 
This article does not indict international economic statistics in toto. But it does suggest that they deserve skeptical examination when they play prominent roles in global governance. Do they indeed capture what they promise to do? As I have argued above, there is a political core to economic statistics that is hard to ignore once we appreciate the slants that may hide in the data.

The in-built biases of international economic statistics clearly limit their ability to play these roles impartially. To build statistics, we need to decide what to measure, what to include in our measures, how to the weigh and value what we include, and how to attribute the different components geographically. At each juncture, there lurks potential bias. Sometimes the direction is very clear, for example when countability bias sidelines informal activities, subsistence agriculture, or labor in the household. Trade hub bias exaggerates the economic heft of countries that act as major economic conduits, just as stealth-wealth bias downplays the weight of those that suffer from capital flight or see profits siphoned away to evade taxes. In other instances the direction of bias is not immediately clear, but also then, the size of disparities and error margins in international statistics is big enough to suggest potentially large effects.

To be sure, statisticians are not to blame. They recognize the difficulties globalization, digitization, and financialization pose for our figures (this comprehensive account lists many of the core problems: UNECE, Eurostat, and OECD 2011). Rather, it is the demands that we place on statistics, for example, that data be reliable or easily accessible, that unwittingly directs statistical attention in particular directions.

This article has concentrated on economic statistics, yet its lessons travel further. Capitalist and stealth-wealth biases are by definition restricted to the economic realm. Expert attention bias, in contrast, affects public statistics in general. The 17 Sustainable Development Goals (SDGs) have consciously cast the net widely, broken down as they are into 169 targets with their attendant indicators. Even then, scope remains to ask to what degree these targets reflect specific viewpoints on, for example, what counts as good-quality education (SDG 4), gender equality (SDG 5) or peace, justice and strong institutions (SDG 16). This is not to say that the targets are inappropriate, but simply that there always remains room for a narrow group of experts slanting actual measures in unconscious ways.

Countability bias equally has a wide resonance. In what Muller (2018) has called "the tyranny of metrics," both public and private actors have made performance and monitoring measures ubiquitous. And in their search for easy-to-use indicators they time and again privilege proxies that can be readily quantified-numbers of correct answers in multiple-choice examinations in student assessments, citations in Google Scholar in academic evaluations, and so on. To be fair, the reliability we expect of public metrics argues against proxies that require too much personal judgment. Some countability bias may be unavoidable. But that does not absolve the producers and the users of these data to be attentive to the skew that this bias may introduce in public assessments and policies.

What is to be done? As we have argued elsewhere, academics using these datawhether in large-n analysis or as single data points in qualitative narratives - should assess much more carefully how data defects might mar their analyses (Linsi and 
Mügge 2019). The focus here is on safeguarding the essential role of statistics in international politics. There is no simple, quick fix. If there was, statisticians would have embraced it long ago-they have plucked the low-hanging fruit for statistical improvements already. Policymakers should develop a mind-set that habitually asks how inevitable slants in international economic data may affect their ability to answer any particular question. If services trade is really pertinent to a policy issue, merchandise trade data clearly are insufficient. Gross trade figures may be good gauges of economic interdependence; net trade figures would be better to understand who earns money by selling products abroad. Actual flows data may be useful to understand where money is being earned; it is misleading when we study actual productivity, because it conflates productivity and pricing power. The utility of data depends on the specific question asked; blanket "trade" figures may be more confusing than revealing.

The complex international division of labor, the knowledge intensity of the contemporary economy, and the growing degree of digitization are unlikely to be reversed in the near future. Initiatives such as country-by-county reporting are intended to ameliorate parts of the stealth-wealth bias, but other biases are bound to remain with us. Policymakers should therefore avoid international or bilateral agreements that rely excessively on numerical targets. Otherwise, they may set themselves up for acrimonious disputes of what the "right" figures are and, in the ensuing spats, further undermine the credibility of the international economic statistical enterprise as a whole. In essence, the key is to "know thy data" and to ignore it if the biases are so substantial that they undermine rather than aid meaningful deliberation.

Acknowledgements This research has been supported by the European Research Council Starting Grant FICKLEFORMS (Grant \# 637883) and the Netherlands Organisation for Scientific Research NWO Vidi project 016.145.395. Details are available on www.fickleformulas.org. I am very grateful to the members of the FickleFormulas team and in particular to the participants of the workshop The Normative Basis of Global Governance held on 29/30 September 2018 at the Fudan Institute for Advanced Study in Humanities and Social Sciences, Shanghai, China, as well as to the editors of this special issue and the reviewers.

\section{Compliance with Ethical Standards}

Conflict of interest The author states that there is no conflict of interest.

Open Access This article is distributed under the terms of the Creative Commons Attribution 4.0 International License (http://creativecommons.org/licenses/by/4.0/), which permits unrestricted use, distribution, and reproduction in any medium, provided you give appropriate credit to the original author(s) and the source, provide a link to the Creative Commons license, and indicate if changes were made.

\section{References}

Abolafia, Mitchel Y. 2010. Narrative Construction as Sensemaking: How a Central Bank Thinks. Organization Studies 31(1): 349-367.

Baldwin, Richard. 2017. The Great Convergence. Information Technology and the New Convergence. Cambridge MA: Harvard University Press.

Bean, Charles. 2016. Independent Review of UK Economic Statistics. London. 
Beckert, Jens. 2016. Imagined Futures: Fictional Expectations and Capitalist Dynamics. Cambridge, Massachusetts: Harvard University Press.

Bloch, Debra, and Falilou Fall. 2015. Government Debt Indicators. Paris: Understanding the Data. https ://doi.org/10.1787/5jrxv0ftbff2-en.

Block, Fred. 1977. The Origins of International Economic Disorder. Berkeley: University of California Press.

Broome, André, and Joel Quirk. 2015. The Politics of Numbers: The Normative Agendas of Global Benchmarking. Review of International Studies 41(05): 813-818.

Bruner, Jennifer, Dylan G Rassier, and Kim Ruhl. 2018. Multinational Profit Shifting and Measures Throughout Economic Accounts. Washington DC. https://www.bea.gov/system/files/papers/WP201 8-3.pdf.

Bryan, Dick, Michael Rafferty, and Duncan Wigan. 2017. From Time-Space Compression to Spatial Spreads. Situating National Liquidity in Global Financial Liquidity. In Money and Finance after the Crisis. Critical Thinking for Uncertain Times, eds. Brett Christophers, Andrew Leyshon, and Geoff Mann, 43-68, Hoboken, NJ: Wiley.

Christensen, Rasmus. 2018. "It's an Art, Not a Science": Professionalisation and Global Governance in the Case of Transfer Pricing. In Paper Presented at the SASE Annual Convention, 27-29 June 2018, Kyoto, Japan.

Costanza, Robert, et al. 1997. The Value of the World's Ecosystem Services and Natural Capital. Nature 387: 253-260.

Coyle, Diane. 2014. GDP. A Brief but Affectionate History. Princeton: Princeton University Press.

Data Revolution Group. 2014. A World That Counts: Mobilising the Data Revolution for Sustainable Development.

de Cecco, Marcello. 1979. Origins of the Post-War Payments System. Cambridge Journal of Economics 3(1): 49-61.

de Vlieger, Jessica, and Daniel Mügge. 2018. Fuzzy Debt. FickleFormulas working paper 2018-03, available at https://www.fickleformulas.org/images/pdf/FFWP\%202018-03\%20deVlieger\%20 M\%C3\%BCgge\%20Fuzzy\%20Debt.pdf.

Fichtner, Jan. 2016. The Anatomy of the Cayman Islands Offshore Financial Center: Anglo-America, Japan, and the Role of Hedge Funds. Review of International Political Economy 23(6): 1034-1063.

Finér, Lauri, and Matti Ylönen. 2017. Tax-Driven Wealth Chains: A Multiple Case Study of Tax Avoidance in the Finnish Mining Sector. Critical Perspectives on Accounting 48: 53-81.

Fogel, Robert, Enid Fogel, Mark Guglielmo, and Nathaniel Grotte. 2013. Political Arithmetic. Simon Kuznets and the Empirical Tradition in Economics. Chicago: Chicago University Press.

Frieden, Jeffrey. 1991. Invested Interests: The Politics of National Economic Policies in a World of Global Finance. International Organization 45(4): 425-452.

Garcia-Bernardo, Javier, Jan Fichtner, Frank W. Takes, and Eelke K. Heemskerk. 2017. Uncovering Offshore Financial Centers: Conduits and Sinks in the Global Corporate Ownership Network. Scientific Reports 7.

Graeber, David. 2011. Debt. A History of the First 5000 Years. New York: Melville House.

Guvenen, Fatih, Raymond Mataloni, Dylan Rassier, and Kim Ruhl. 2017. Offshore Profit Shifting and Domestic Productivity Measurement. Cambridge MA.

Helleiner, Eric. 1994. States and the Reemergence of Global Finance: From Bretton Woods to the 1990s. Ithaca: Cornell University Press.

Hirschman, Daniel. 2016. Inventing the Economy. Or: How We Learned to Stop Worrying and Love the GDP. PhD thesis, University of Michigan.

Hollyer, James R., B. Peter Rosendorff, and James Raymond Vreeland. 2011. Democracy and Transparency. The Journal of Politics 73(4): 1191-1205. https://doi.org/10.1017/S0022381611000880.

Jerven, Morten. 2013. Poor Numbers: How We Are Misled by African Development Statistics and What to Do About It. Ithaca: Cornell University Press.

Kelley, Judith G. 2017. Scorecard Diplomacy. Grading States to Influence Their Reputation and Behavior. Cambridge: Cambridge University Press.

Kendrick, John W. 1970. The Historical Development of National-Income Accounts. History of Political Economy 2(2): 284-315.

Kenessey, Zoltan. 1994. The Accounts of Nations. Amsterdam: IOS PRESS.

Kerner, Andrew, Morten Jerven, and Alison Beatty. 2017. Does It Pay to Be Poor? Testing for Systematically Underreported GNI Estimates. Review of International Organizations 12(1): 1-38. 
Leins, Stefan. 2018. Stories of Capitalism. Inside the Role of Financial Analysts. Chicago: University of Chicago Press.

Lepenies, Philipp. 2013. Die Macht Der Einen Zahl: Eine Politische Geschichte Des Bruttoinlandsprodukts. Suhrkamp Verlag.

Lequiller, Francois, and Derek Blades. 2006. Understanding National Accounts. Paris: OECD.

Linsi, Lukas, and Daniel Mügge. 2019. Globalization and the growing defects of international economic statistics. Review of International Political Economy. https://doi.org/10.1080/09692290.2018.15603 53.

Markhonko, Vladimir. 2014. Asymmetries in Official International Trade Statistics and Analysis of Globalization. Mexico: Aguascalientes.

Masood, Ehsan. 2016. The Great Invention. The Story of GDP and the Making and Unmaking of the Modern World. New York: Pegasus Books.

McCormick, Ted. 2009. William Petty and the Ambitions of Political Arithmetic. Oxford: Oxford University Press.

Morgenstern, Oskar. 1963. On the Accuracy of Economic Observations, 2nd ed. Princeton, NJ: Princeton University Press.

Mosley, Layna. 2003. Global Capital and National Governments. Cambridge: Cambridge University Press.

Mügge, Daniel. 2016. Studying Macroeconomic Indicators as Powerful Ideas. Journal of European Public Policy 23(3): 410-427.

Mügge, Daniel, and Lukas Linsi. 2017. Trump Uses Bad Trade Statistics. But There's a Bigger Problem. The Washington Post. https://www.washingtonpost.com/news/monkey-cage/wp/2017/03/09/trump -uses-trade-statistics-to-back-up-his-claims-but-how-accurate-are-they/ (August 28, 2018).

Mügge, Daniel, and James Perry. 2014. The Flaws of Fragmented Financial Standard Setting: Why Substantive Economic Debates Matter for the Architecture of Global Governance. Politics and Society 42(2).

Muller, Jerry. 2018. The Tyranny of Metrics. Princeton: Princeton University Press.

Nitzan, Jonathan, and Shimshon Bichler. 2009. Capital as Power. A Study of Order and Creorder. Abingdon: Routledge.

Perry, James. 2009. Goodwill Hunting. Accounting and the Global Regulation of Economic Ideas. PhD thesis, Vrije Universiteit Amsterdam.

Philipsen, Dirk. 2015. The Little Big Number. How GDP Came to Rule the World and What to Do About It. Princeton: Princeton University Press.

Porter, Theodore. 1995. Trust in Numbers. The Pursuit of Objectivity in Science and Public Life. Princeton: Princeton University Press.

Reinhart, Carmen, and Kenneth Rogoff. 2009. This Time Is Different: Eight Centuries of Financial Folly. Princeton: Princeton University Press.

Savage, James D. 2005. Making the EMU: The Politics of Budgetary Surveillance and the Enforcement of Maastricht. Making the EMU: The Politics of Budgetary Surveillance and the Enforcement of Maastricht. Oxford: Oxford University Press.

Scott, James. 1998. Seeing Like a State. How Certain Schemes to Improve the Human Condition Have Failed. New Haven: Yale University Press.

Seabrooke, Leonard, and Duncan Wigan. 2017. The Governance of Global Wealth Chains. Review of International Political Economy 24(1): 1-29.

Sedlacek, Tomas. 2011. Economics of Good and Evil. The Quest for Economic Meaning from Gilgamesch to Wall Street. Oxford: Oxford University Press.

Sharman, Jason. 2010. Offshore and the New International Political Economy. Review of International Political Economy 17(1): 1-19.

Shaxson, Nicholas. 2012. Treasure Islands: Uncovering the Damage of Offshore Banking and Tax Havens. New York: Palgrave Macmillan.

Smith, John. 2012. The GDP Illusion. Value Added Versus Value Capture. Monthly Review 64(3): 97-113.

Stiglitz, Joseph E., Amartya Sen, and Jean-Paul Fitoussi. 2010. Mismeasuring Our Lives: Why GDP Doesn't Add Up. New York: New Press.

Studenski, Paul. 1958. The Income of Nations: Theory, Measurement and Analysis Past and Present. New York: New York University Press.

Tørsløv, Thomas, Ludvig Wier, and Gabriel Zucman. 2018. The Missing Profits of Nations. Cambridge MA. http://www.nber.org/papers/w24701. 
UNCTAD. 2016. World Investment Report 2016 - Investor Nationality: Policy Challenges. Geneva: United Nations Publications.

UNECE, Eurostat, and OECD. 2011. The Impact of Globalization on National Accounts. New York and Geneva: United Nations.

Varga, Mihai. 2018. Subsistence' Readings: World Bank and State Approaches to Commercialising Agriculture in Post-Communist Eurasia. Journal of Development Studies. https://doi.org/10.1080/00220 388.2018.1453607.

Ward, Michael. 2004. Quantifying the World: UN Ideas and Statistics. New York: Indiana University Press.

Waring, Marilyn Joy. 1999. Counting for Nothing: What Men Value and What Women Are Worth. Toronto: University of Toronto Press.

Wise, Norton (ed.). 1995. The Values of Precision. Princeton: Princeton University Press.

Ylönen, Matti, and Teivo Teivanen. 2018. Politics of Intra-Firm Trade: Corporate Price Planning and the Double Role of the Arm's Length Principle. New Political Economy 23(4): 441-457.

Daniel Mügge is professor of political arithmetic at the University of Amsterdam. He currently leads a research project that investigates the political economy of macroeconomic indicators. 